\title{
Governing Children's Rights in Global Social Policy-International Organizations and the Thin Line Between Child Protection and Empowerment
}

Anna Holzscheiter

\section{InTRODUCTION-LOCATING ChILDREN's Rights in Global Social Governance ${ }^{1}$}

Without doubt, the protection, welfare and well-being of children lie at the heart of social policy, domestically and in global governance. Both the Millennium Development Goals (MDGs) and, to a lesser extent, the Sustainable Development Goals (SDGs) mirror the particular vulnerability and needs of children in the areas of international development cooperation they focus on. Children constitute a group that is most relevant to some of the core areas of social policy, such as education, social welfare and healthcare-particularly for very young children (i.e. immunization

${ }^{1}$ I thank Martha van Bakel for invaluable research support in writing this chapter.
A. Holzscheiter $(\bowtie)$
Institute of Political Science, TU Dresden, Dresden, Germany
e-mail: anna.holzscheiter@tu-dresden.de
(C) The Author(s) 2021
K. Martens et al. (eds.), International Organizations in Global
Social Governance, Global Dynamics of Social Policy, https://doi.org/10.1007/978-3-030-65439-9_6 
regimes). The centrality of child welfare in (global) social policy, however, is poorly reflected in the social policy literature which pays little attention to this specific age group (Yeates 2014) or reduces relevant social policies to child abuse, child poverty and child labor (Yeates and Holden 2009). It is, thus, all the more important to include children and their rights in a compendium on global social governance.

Despite the centrality of children in (global) social policy, any attempt to discuss children's rights in light of global social governance will inevitably have to address that global social policies targeting children and their social environment are situated in a field of tension. The tension lies between traditional child protection approaches, which are based on an assessment of children's (special) needs, and more progressive approaches, which recognize children's rights as human rights and reflect the changing legal status of the child in international politics. To think of global social policy under the rubric of 'children's rights' thus implies a changing status of children as a sociopolitical group in global governance. This status is associated with rising claims on behalf of children (or by children themselves) for equality and social justice, a turning-away from primarily needsbased approaches to child protection and a stronger focus on the participation of children and youth in the making, implementation and assessment of global social policy. Consequently, any discussion of child protection and children's rights in the context of global social policy will have to address fundamental questions that have confronted national and international law and the politics of children's rights for a long time: How to resolve the numerous conflicts of (best) interest and rights between children, their parents or guardians, and public authorities as they are reflected, for example, in public discourses on abortion, child custody or child abuse and neglect?

Global child rights governance-also in its narrower focus on social issues and policies such as health, housing, food security, social benefits or education-has been evolving toward a field of global governance marked by a growing visibility of children and stronger claims for social justice made on their behalf, or sometimes even directly made by children themselves. Thus, this contribution will not only address how international organizations have seized and 'governed' matters of child protection and child rights in their activities-it will also place these activities in the context of an increasing recognition of children's social, political and economy agency and, as a consequence, in the context of claims toward more direct and meaningful involvement of children as "affected persons" of social policy in international organizations (Holzscheiter 2018). 
Children's rights in contemporary international politics are comprised of a mixture of general human rights principles and specific rights tailored to the unique needs and situation of human beings below 18 years of age. In global politics, those rights are anchored in the UN Convention on the Rights of the Child (UNCRC or CRC), which was adopted in 1989 by the UN General Assembly and which, in its 41 substantive articles, comprises rights from all generations and 'classes' of human rights, spanning civil, political, social, economic and cultural rights. While global social governance for children's rights (as part of a broader child rights regime) is composed of a whole array of international rules, organizations and collaborative structures, the UNCRC certainly constitutes the backbone of and core normative reference in international social policymaking relevant to children.

In its widely noted General Comment No. 5 on the General Measures of implementation of the Convention on the Rights of the Child, the CRC has underlined the four general principles or pillars underlying a contemporary understanding of children's rights: children's right to life and survival; the principle of the best interests of the child; the child's right to be heard; and non-discrimination (Committee on the Rights of the Child 2003). These principles reflect the special vulnerability of children and they are of immediate relevance to global social governance. Thus, global social governance geared toward children's rights applies to areas that are concerned with the survival and well-being of children, takes into account the best interests of the child, ensures that children are being granted possibilities to articulate their viewpoints and interests, and makes certain that children are not discriminated against in social policy—neither on the basis of their age nor on the basis of the many other potential reasons for discrimination such as sex, color, political opinion, national origin, disability, religion and so forth.

As I argue in this chapter, thinking about global social governance in terms of children's rights rather than child protection necessitates paying heed to all types of human rights, not just privileging social and economic rights. This is because the changing status of the child in international law toward a holder of rights also has profound implications for addressing questions of equality and social justice. The ensuing discussion of core actors, actor constellations, discourses and 'leitmotifs' in global social policy on children's rights will demonstrate three things: first, a constant broadening of the 'catalogue' of social policy issues considered relevant for ensuring the well-being of and adequate living conditions for children. 
The idea that children are bearers of human rights has thus dislocated childhood from a narrow, traditional social policy agency focusing on health, social security, education, housing, childcare, labor and food security toward more fundamental social questions such as discrimination (i.e. gender, age), social exclusion, inequality and (distributive) justice, including intergenerational justice. ${ }^{2}$ Second, the contribution aims to highlight the implications of reconsidering more traditional, protectionist and objectifying approaches toward children in the context of changing interpretations of children's rights, particularly for global social governance. Third, the chapter exposes the centrality of the United Nations and its various specific organizations-particularly those active in development cooperation-in addressing and implementing child rights norms in global social governance. As the discussion below will show the 'moral authority' of the United Nations in the area of child rights is grounded in the circumstance that the UNCRC serves as the focal legal and normative reference for virtually all organizations aiming to become more child rights-oriented in social policymaking and implementation. However, the chapter also discusses how global and regional organizations focused on social policy beyond the UN relate to child rights in their organizational philosophies and practical activities. Such a broadening of the IO population beyond the United Nations allows us to portray global social governance related to 'children's rights' as a contested space in which neither the meaning of 'children's rights' nor the necessity of prioritizing the 'child rights' lens or 'frame' in social policy are undisputed.

\section{The History of Children's Rights in International Organization AND LAW}

Social policy with regard to children and the increasing global governance of childhood as a separate sphere of international cooperation has quite a long history. This history is marked by three distinct, coevolving processes: first, the gradual segregation of childhood as a distinct sphere of social life and the dissociation of childhood from sites that became associated with adults (work, street, factory); second, an increasing awareness of universal childhood experiences emerging from new academic sub-disciplines such as pediatrics, pedagogy or developmental psychology; and third, related to

\footnotetext{
${ }^{2}$ See contributions on education (Niemann and Martens), disability (Schuster and Kolleck), health (Kaasch), food (Wolkenhauer) in this volume.
} 
these two processes, a steadily growing internationalization of childhood, reflected in a diversification of international legal rules, institutions and policies specifically targeting children and adolescents. In the context of these three large processes, the meaning of 'children's rights' in domestic and international politics has considerably changed and expanded.

In 1973, Hilary Rodham (now Clinton) famously related to children's rights as a "slogan in search of a definition" (Rodham 1973, 487). As much as the contours of children's rights have become more defined since then, they continue to be appropriated by a diverse array of actors and often reflect quite different approaches toward the well-being of children. Not surprisingly, childhood constitutes a much-contested concept, laden with conflicting ideologies and values - and also an object of reference onto which very diverse social and moral expectations are projected (Rizzini 2001, 315). Revisiting twentieth-century child protection policies and debates in international politics, it is clear that despite a terminology of 'children's rights', discourses on children and childhood were, for a long time, dominated by paternalistic, objectifying perspectives that presented children as inherently irrational, innocent, vulnerable and mute (Holzscheiter 2010). It was only in the second half of the twentieth century and, particularly, in the course of the 1970s and 1980s-with new perspectives on children in sociology, psychology and pedagogy-that children's rights were no longer exclusively couched in a language of 'salvation' and benevolence. Rather, it was possible to observe a shift in concern for protecting children to a concern for protecting their rights (Freeman 1983, 18). However, while debates became gradually infused with a new terminology of children's rights as legal claims rather than moral goods, international law and policies still reflect a tension between a child rights perspective on child well-being on the one hand and a needsbased perspective on the other (McGillivray 1997, 14).

With the adoption of the UNCRC and its clear definition of children as all human beings between 0 and 18 years of age, international law and politics on children's rights expanded toward adolescence as a legal gray zone. As I discuss further in later sections of this contribution, the intricacies associated with including adolescents or quasi-adults in an international child rights regime are only unsatisfactorily and artificially 'resolved' by maintaining separate international rules and institutions for children and youth. At the same time, the drafters of the UNCRC sought to incorporate a certain flexibility in this treaty by introducing the idea or 'formula' of children's evolving capacities, that is, their gradually increasing 
capacity to make informed judgments, articulate their viewpoints and become independent rights-holders (Holzscheiter 2010; Hammarberg 1990). This new identity of the child in international law is most strikingly expressed in Article 12 of the Convention: "States Parties shall assure to the child who is capable of forming his or her own views the right to express those views freely in all matters affecting the child, the views of the child being given due weight in accordance with the age and maturity of the child." The contemporary children's rights regime anchored in the CRC thus captures an image of the child as maturing toward a competent social, political and economic human being. In the following sections, I will discuss the historical evolution of children's rights in the context of global social policies.

\section{Children's Rights and the Recognition of Children's Vulnerability and Special Status}

The growth in specific legal provisions, policies and organizations addressing children in international politics paralleled a general trend in international law-making in the second half of the twentieth century. The history of international organizations, particularly after 1945, is also a history of the growing recognition of the special vulnerabilities of specific groupssuch as women, indigenous peoples, ethnic minorities, migrant workers or people living with disabilities - and their need for protection. It is in the context of this dynamic that children were also becoming a group that was granted specific rights, with more and more international organizations creating specific departments for child-focused activities or even special international programs catering to the situation of children, such as the Partnership for Maternal, Newborn and Child Health, for example. ${ }^{3}$

Historically, international legislation targeting children specifically could be found in international human rights law, humanitarian law and labor law (van Bueren 1998, xix). After 1945, the creation of special funds and programs, most notably the United Nations Children's Fund (UNICEF), but also the United Nations Development Programme (UNDP), resulted in a significant expansion of child-focused activities, especially in the context of development cooperation. It is also in these areas that social policy activities of international organizations were becoming increasingly justified and extended with reference to child rights principles.

\footnotetext{
${ }^{3}$ Partnership for Maternal, Newborn and Child Health, see: https://www.who.int/ pmnch/en/. Accessed February 25, 2020.
} 


\section{Early Global Social Policy for ChIldren: InTERnATIONAL COOPERATION ON ECONOMIC and Sexual Exploitation}

Among the earliest provisions dealing with child-specific issues were those that targeted labor, trafficking and humanitarian law. In fact, the first international treaties explicitly including children in their scope were those that addressed exploitation, either in the context of labor regulations or in the context of slavery. In 1904, an International Agreement for the Suppression of the "White Slave Traffic" was adopted by the International Conference on Traffic in Women and Children based in Paris, dealing explicitly with children as trafficked persons (Marshall 1999, 112). Some years later, the League of Nations covered the same issue area by an International Convention for the Suppression of Traffic in Women and Children (1921) and the Slavery Convention (1926). Equally important for global social governance was Convention No. 5 on the minimum age for employment, which figured among the first Conventions formulated by the International Labour Organization (ILO) and was adopted at the ILO's very first session in 1919. The ILO Convention No. 5 prohibits the work of children under the age of 14 in industrial establishments. Further ILO Conventions regulating child labor were added in 1973 when the ILO reformulated the Minimum Age Convention, adopting Convention 138 concerning the Minimum Age for Admission to Employment. The new Convention 138, which supplements Convention 5, in fact obliged States Parties to fix a minimum age for admission to employment and work and to pursue a national policy designed to guarantee the effective abolition of child labor. It was, however, specifically in the context of ILO Convention No. 198 on the 'Worst Forms of Child Labour' that the tensions inherent to the children's rights regime under the UNCRC became acutely visible. This had a lasting and rather conflictual impact on the relationship between transnational child worker associations advocating for child participation and recognition of children as social and economic agents on the one hand, and traditional, protective, abolitionist international organizations and actors advocating for the widest abolition of child labor possible on the other hand. 


\section{Gender, Girls and Global Social Policy}

It was in the context of discussions on prohibiting child marriage that gender issues and the 'girl child' emerged for the first time in the United Nations. In 1963, the UN adopted a Convention on Consent to Marriage, Minimum Age for Marriage and Registration of Marriages which foresaw that children should neither be allowed nor coerced to marry, working toward "eliminating completely child marriages and the betrothal of young girls before the age of puberty" (Rosenblatt 2000, 187). On a more general level, it was of course the UN Convention on the Elimination of All Forms of Discrimination Against Women (CEDAW) of 1979 that elevated gender discrimination to a cross-cutting theme in international politics and also referred to children in the context of gender discrimination. It contains several articles that have a bearing on children, both in terms of the relationship between mothers and their children as well as with regard to the special situation of the girl child.

In Article 5(b), CEDAW envisages that "family education includes a proper understanding of maternity as a social function and the recognition of the common responsibility of men and women in the upbringing and development of their children," it being understood that the interest of the child is the primordial consideration in all cases (van Bueren 1993, 57). Relating to the girl child, Article 10 calls for equal opportunities in education and for equal respect for men and women.

These provisions testify to a growing recognition of the child's best interests in family matters and, by defining them as superior to the interests of other parties (parents, public authorities, custodians), a slow but steady elevation of the child's status in international law. The growing recognition of gender dynamics as being relevant to social governance and the identification of the 'girl child' as a particularly vulnerable group of children resulted in the creation of specific programs and policies targeting the discrimination of girls in social policy, most notably in education, and, to a lesser extent, in health. In 1990, $44 \%$ of the programs funded by the World Bank proposed activities to improve female education, and the United Nations Educational, Scientific and Cultural Organization (UNESCO) adopted the World Declaration on Education for All. These landmarks were the starting point for a gradual mainstreaming of gender issues into the activities of IOs, which also meant an increasing focus on girls as especially vulnerable and in need of social protection (Vaughan 2010). More recently, multi-stakeholder initiatives have emerged in this 
area, such as the United Nations Girls' Education Initiative (UNGEI) established in 2008. The changing status of the child in international politics has also been reflected in the activities of a number of international organizations beyond those of an explicit child-related mandate such as UNICEF (Fig. 6.1).

\section{The Evolution of Children's Rights IN INTERNATIONAL LAW}

With the adoption of the UNCRC, all those different provisions scattered among previously existing international legal documents were drawn together in what was then the most comprehensive international human rights treaty ever written and adopted. The CRC, however, was not the first international legal document devoted solely to children, their wellbeing and their rights. The League of Nations had formulated a very short set of moral aspirations for children in its 1924 Declaration of the Rights of the Child ("The child that is hungry must be fed..."), ${ }^{4}$ and the UN set out to formulate a brief catalog of children's rights for the first time in its 1959 Declaration of the Rights of the Child up until the 1970s; however, the international politics on childhood was, essentially, a politics of protecting children under exceptional circumstances-those exploited, hungry, in situations of armed conflict or violence, disabled or neglected. Thus, for a long time, children's rights were placed in the context of social policy toward those most in need, framed in terms of charity, benevolence and caring for those most vulnerable and exposed.

In the context of this rather narrow child rights perspective and agenda, the CRC stood out as a groundbreaking document, formulating a set of universal rights to be claimed by each and every child (i.e. the individual child). It was also the first international treaty that identified concrete duty-bearers, namely the States Parties, but also extended duties to parents, families, legal guardians and society at large to ensure, fulfill and respect children's rights. There have been several attempts to categorize and systematize the 41 substantive articles in the CRC. Some authors have suggested to use the ' 3 Ps' (provision, protection, participation) in order to classify children's rights, while others have differentiated alongside the negative/positive divide or, classically, using the differentiation between

\footnotetext{
${ }^{4}$ Geneva Declaration of the Rights of the Child of 1924. https://www.humanium.org/ en/text-2/. Accessed February 25, 2020.
} 


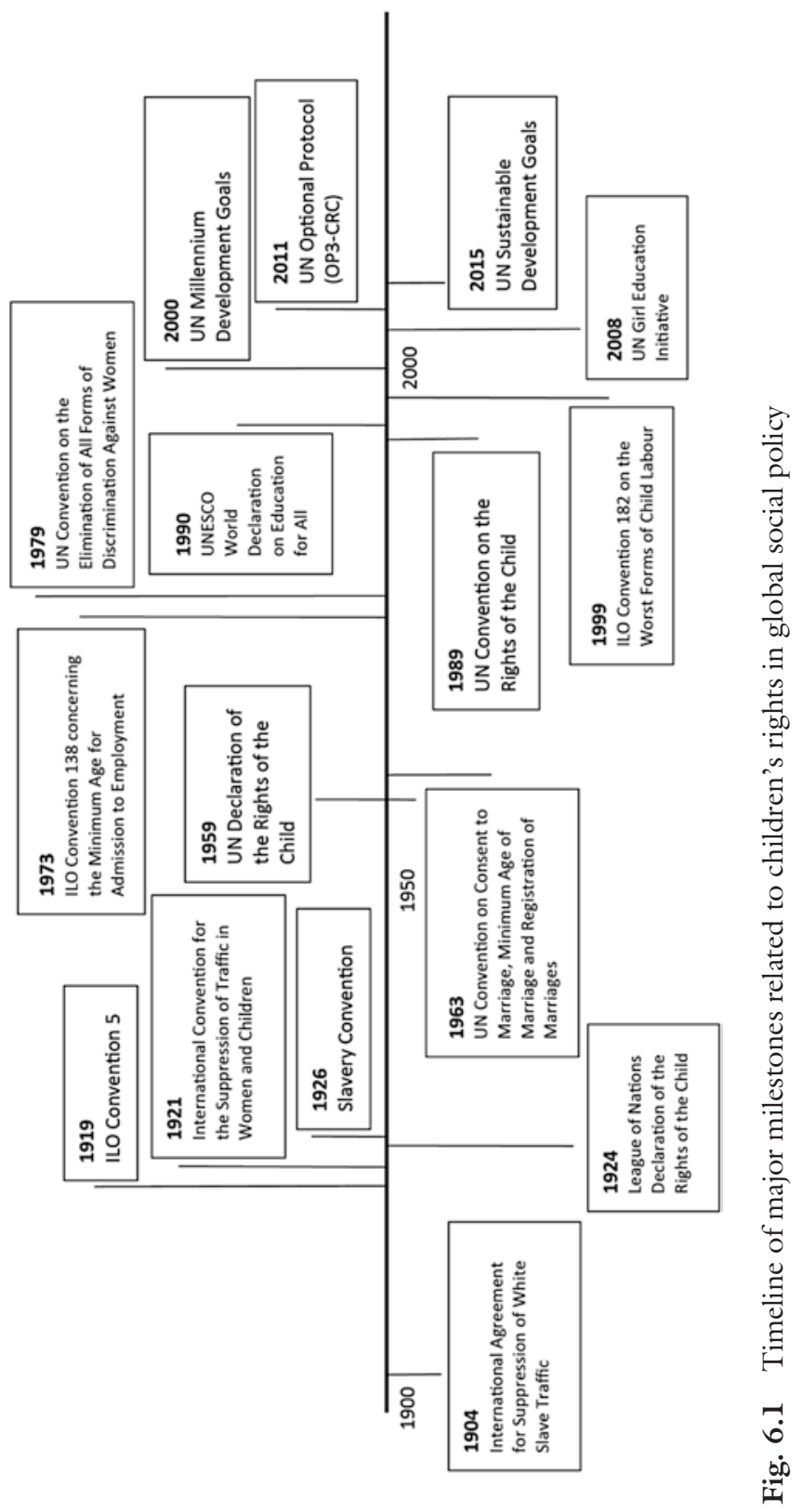


political, civil, economic, social and cultural rights. Beyond these largely legal exercises, however, the CRC is also interesting in the way it seeks to capture a universal image of childhood to which all of the drafters of the CRC could agree. Although the CRC contained a number of groundbreaking elements that extended children's rights toward adolescents and thereby dramatically increased the number of rights-holders, it was also still firmly grounded in long-standing protective and paternalistic images of childhood. At the same time, it also sought to give expression to culturally varying notions of childhood and child protection. As I will discuss below, the contemporary discussion on the CRC is nevertheless not only preoccupied with questions of compliance, governance and implementation-it also interprets the CRC as essentially a reflection of Western or Northern ideas and ideals of childhood, as an instrument of power and as an example of governmentality.

With regard to monitoring and assessing the national implementation of children's rights principles, the Committee on the Rights of the Child occupies a paramount role. Under the CRC, States Parties are obliged to submit reports on their progress in implementing the provisions of the CRC on a regular basis. Article 44 of the CRC stipulates that States Parties must submit their first report after a maximum of two years after ratification, thereafter every five years. These reports are then reviewed and commented on by the CRC Committee which consists of 18 independent experts (originally only 10 experts) and meets annually in Geneva. The Committee is not only guiding States Parties in their implementation through its Concluding Observations - it also revisits the rights of the child in light of new issues and legal interpretations through its General Comments. The Optional Protocol to the UN Convention on the Rights of the Child on a Communications Procedure (OP3-CRC) - which was adopted in 2011 and entered into force in 2014-constitutes yet another groundbreaking step in the fortification of the status of the child as an individual and active rights-holder under international law. The Optional Protocol establishing a Complaints Mechanism for children under international law foresees the possibility for individuals or groups of individuals to submit communications directly to the CRC Committee if they are within the jurisdiction of a State Party, claiming to be the victims of a violation of either the CRC or its Optional Protocols committed by the State Party.

Narrowing down a discussion of children's rights to global social governance, it appears that the contemporary child rights regime covers the 
majority of the substantive social governance issues assembled in this edited volume: employment and child labor; care; migration; education; gender; disability; health; water (as in access to clean and safe drinking water); and food security. For all of these dimensions of global social governance, legal provisions exist specifically for children.

\section{The Contemporary IO Landscape \\ and 'Organizational Ecology' of Children's Rights}

\section{Types, Roles and Constellations of IOs in Global Social Governance}

Revisiting global social governance as it relates to children's rights brings to light an extremely densely populated, pluralist and complicated landscape of intergovernmental, non-governmental and hybrid, public-private organizations and networks. It is nevertheless possible to identify several central-and a large number of peripheral-international organizations and rule-systems protecting children and promoting their rights in global social policy. These organizations can be classified using classical typologies such as standard-setting organizations versus operational organizations versus financing organizations, or general IOs versus specialized organizations and programs. With regard to monitoring State Parties' compliance with their obligations under the CRC, the Committee on the Rights of the Child stands out as the most central actor, supported, of course, by a broad array of non-state actors and other crucial mechanisms such as the Universal Periodic Review. Due to its history as the first special fund set up for children, UNICEF stands out as the most well-known international organization working on issues of child protection and children's rights. Despite its outstanding role, however, UNICEF only began to embrace the philosophy and terminology of children's rights in the late 1990s. In fact, the organization had been a mostly invisible actor in the drafting of the UN Convention on the Rights of the Child and, due to its focus on countries in the Global South, had been very reluctant to embrace a child rights agenda that would lead away from its traditionally needsbased, child protection approach.

Three standard-setting international organizations stand out as particularly pertinent to global social policy for children: the International Labour Organizations (ILO) as the core rule-making authority in the area of child labor and, to a lesser extent, the World Health Organization (WHO) and 
the United Nations Educational, Scientific and Cultural Organization (UNESCO). Even though the World Bank does not have a separate programming area for children, its project portfolio reveals that child health and primary education, in particular, are recurring focal points of World Bank-funded projects. Other international organizations immediately relevant to global social policy for children are UNDP and the United Nations Population Fund (UNFPA). A broader trend starting in the 1990s (but particularly after 2000) toward the creation and institutionalization of more hybrid, public-private (or multi-stakeholder) initiatives has also involved the establishment of a broad array of issue-specific or problem-specific partnerships for health, education, water, sanitation or food security targeting children specifically. Outstanding examples of such partnerships or initiatives are the Vaccine Alliance (GAVI), the Global Fund to Fight Aids, Tuberculosis and Malaria, or the Partnership for Maternal, Newborn and Child Health. Even more recently, a number of inter-agency initiatives involving two or more international organizations (such as the European Union (EU) and UNICEF, for example) have been set up in order to jointly address issues such as child malnutrition. ${ }^{5}$ At present, the Sustainable Development Goals and Agenda 2030 are the main drivers behind increasing inter-agency collaboration and coordination in development cooperation, as well as cooperation focused on children as a specific group.

As an expression of the growing visibility and salience of child-related matters and the increasing acceptance of child protection norms in all areas of international politics, it appears that organizations and bodies that had hitherto not dealt with children's issues and rights have also become involved in this area. Former child soldiers have been speaking in front of the Security Council on matters related to children and armed conflict. The International Criminal Court has been investigating the use of child soldiers in armed conflict as a crime against humanity and a basis for prosecuting war crimes. The UN Global Compact has included the "effective abolition of child labour" (Principle 5) in its 10 Principles for socially responsible global business. Together with the ILO, the Global Compact

\footnotetext{
${ }^{5}$ Generally see: UNICEF, "What we do." https://www.unicef.org/eu/what-we-do. Accessed February 25, 2020; UNICEF Ethiopia, "EU Partnership Paves the Way for Better Nutrition for Children and Women in Ethiopia." https://unicefethiopia.org/2017/03/01/ eu-partnership-paves-the-way-for-better-nutrition-for-children-and-women-in-ethiopia/. Accessed February 25, 2020.
} 
has set up a Child Labour Platform for fostering dialogue on best practices and sharing experiences, particularly in abolishing child labor in the supply chain. ${ }^{6}$ As an extension to these activities, UNICEF, the Global Compact and Save the Children (the most powerful transnational NGO in the field of child protection and children's rights) have developed the 'Children's Rights and Business Principles' in order to highlight the specific situation, needs and rights that children have and thereby give more concrete shape to the UN Business and Human Rights principles.

It is also on the level of regional organizations such as the Organisation for Economic Co-operation and Development (OECD), the European Commission and the Council of Europe that an increasing recognition of child rights in the context of discourses and policies on social inclusion/ exclusion is observable. The necessity of becoming more receptive to human rights standards in the creation and implementation of social policies is clearly visible, at least at the level of programmatic language of the EU and the OECD, especially where children are concerned. In her recent paper, Kišūnaitè assesses the extent to which "European governance and policies create a favourable framework for protecting children's rights" (Kišūnaitė 2019, 173). Her paper portrays the European Union as a latecomer with regard to incorporating child rights principles in its policymaking, claiming that "children's rights protection arrived at the forefront of EU policies just ten years ago" (173). So far, in the context of the European Union, child rights have been explicitly included in Art. 3.3 of the Treaty of Lisbon and the EU Charter of Fundamental Rights (Article 24). In 2011, the EU adopted its Agenda for the Rights of the Child as an instrument toward the mainstreaming of child rights in all EU policy spheres. In this EU Agenda, a few selected areas of action are identified, including the protection of children "when they are vulnerable"-the area that most clearly relates to social policy issues such as poverty and social exclusion, health, disability and education (European Commission 2011).

A recurrent theme in discourses on children's rights and discrimination against children in national and international policies has been the availability, dissemination and particularly disaggregation of data for children. As a consequence, global social governance in the name of children's rights has come to embrace an increasing amount of initiatives working toward the improvement of the 'data situation' concerning children. In

\footnotetext{
${ }^{6}$ Global Compact \& ILO, "Share Best Practices on the Child Labour Platform." https:// www.unglobalcompact.org/take-action/action/child-labour. Accessed February 25, 2020.
} 
particular, methodologies for monitoring children's economic and social rights have been described as "exploding" in recent years, such as the development of specific indicators or benchmarks, child rights-based budget analysis or child rights impact assessments (Nolan 2013). Clearly, such initiatives envisage a stronger knowledge base for evidence-based policymaking on behalf of children and, more generally, a stronger visibility of children in the budgets of national authorities and international organizations. ${ }^{7}$ UN Data, the central data repository of the United Nations, ${ }^{8}$ contains a wealth of statistics on the specific situation of children, concerning for example school enrolment, health status or gender inequality. In this regard, the Millennium Development Goals (as well as their successor, the SDGs) with their clear preference for measurable development indicators have contributed significantly to the growth in statistical data on the specific situation of children in social policy areas such as health, education, nutrition and labor. The above-mentioned EU Agenda for the Rights of the Child also calls for better "evidence-based" policymaking in the area of child protection and child rights, asking its member states to establish "child-rights related policy targets" and address "gaps in knowledge about the situation and needs of the most vulnerable groups of children" (European Commission 2011, 5).

As the above makes abundantly clear, the governance of childhood and children's rights through global social policies has evolved from a rather narrow field of international cooperation largely in the hands of UN special agencies and programs such as UNICEF or WHO (administering a rather narrow basic needs agenda) to a central dimension of international policymaking and global governance in all areas of international cooperation. Children's rights can thus be considered a cross-cutting theme or norm-catalog that has found its way into the work and policies of all international organizations in one way or another. When it comes to addressing children's rights in global social policy, most IOs with a specific focus, expertise, and programming area on children deal with social policy issues in low- and middle-income countries. There is, therefore, a strong overlap between global social policy and development cooperation. It is in the context of social policies addressing the Global South, however, that the notion of children's rights confronts particular political and cultural

\footnotetext{
${ }^{7}$ Examples: UNICEF, “UNICEF Data: Monitoring the situation of children and women." https://data.unicef.org/. Accessed February 25, 2020.

${ }^{8}$ UNdata Explorer. http://data.un.org/Explorer.aspx. Accessed February 25, 2020.
} 
challenges. Here, repeatedly, the contemporary children's rights regime has been assessed as "too weak" to significantly change "the material realities of vulnerable children's lives" (Grugel 2013, 19). Children's social policies have been described as being fraught with complexities and "persistent deprivations" (Khadka 2013, 616). Applying a political economy perspective on social rights in the developing world, Khadhka questions the prioritization of rights in the "mainstream child rights discourse" and its usefulness in resource-poor contexts (Khadka 2013, 616) Table 6.1.

Table 6.1 IOs, children's rights and selected recent activities

\begin{tabular}{|c|c|}
\hline Organization & Selected recent activity \\
\hline $\begin{array}{l}\text { United Nations } \\
\text { Children's Fund } \\
\text { (UNICEF) }\end{array}$ & $\begin{array}{l}\text { In partnership with the EU, UNICEF has implemented a } \\
\text { number of policies, programs and actions to reduce malnutrition } \\
\text { and stunted growth in children under } 5 \text { years as articulated in the } \\
\text { UNICEF Strategic Plan 2018-2021 and the EU Nutrition } \\
\text { Action Plan 2014. Examples include: } \\
\text { Since 2016: Partnership for Improved Nutrition in Lao to } \\
\text { improve nutritional status of women and children. } \\
\text { Since } 2018 \text { : West and Central Africa regional project where } \\
225,000 \text { cartons of ready-to-use food were distributed to } \\
\text { children at risk of malnutrition }\end{array}$ \\
\hline International Labour & Since 2015: International Programme on the Elimination of Child \\
\hline Organization (ILO) & $\begin{array}{l}\text { Labour and Forced Labour (IPEC+) Flagship Programme } \\
\text { operates in } 55 \text { countries and aims to eliminate all forms of child } \\
\text { labor by } 2025 \text { and to dismantle systems of forced labor and } \\
\text { human trafficking by } 2030 \text {, in line with the UN } 2030 \text { Sustainable } \\
\text { Development Goals (SDGs) } \\
\text { Since } 2018 \text { : Accelerating action for the elimination of child labor } \\
\text { in supply chains in Africa (ACCEL Africa) implemented in Ivory } \\
\text { Coast, Egypt, Mali, Malawi, Nigeria and Uganda focusing on } \\
\text { cacao, coffee, gold, cotton and tea } \\
\text { Eliminating child labor and forced labor in the cotton, textile and } \\
\text { garment value chains: an integrated approach (co-funded by the } \\
\text { European Union) targeting Burkina Faso, Mali, Pakistan and } \\
\text { Peru to ensure a cotton supply chain free of child labor }\end{array}$ \\
\hline World Health & Since 2013: Global Action Plan for Pneumonia and Diarrhoea \\
\hline Organization (WHO) & $\begin{array}{l}\text { (GAPPD) to end preventable childhood deaths by pneumonia } \\
\text { and diarrhoea by } 2025 \text {, which account for } 29 \% \text { of child deaths } \\
\text { globally } \\
\text { Since 2016: Global Strategy for Women's, Children's and } \\
\text { Adolescent's Health } 2016-2030 \text { to attain the highest standard of } \\
\text { health for women, children and adolescents in line with the UN } \\
2030 \text { Sustainable Development Goals }{ }^{\mathrm{f}}\end{array}$ \\
\hline
\end{tabular}


Table 6.1 (continued)

\begin{tabular}{|c|c|}
\hline Organization & Selected recent activity \\
\hline $\begin{array}{l}\text { United Nations } \\
\text { Education, Scientific } \\
\text { and Cultural } \\
\text { Organization } \\
\text { (UNESCO) }\end{array}$ & $\begin{array}{l}\text { Since 2019: From access to empowerment: UNESCO strategy for } \\
\text { gender equality in and through education 2019-2025 to deliver } \\
\text { the UN's Education } 2030 \text { Agenda as part of the SDGs through } \\
\text { better data, frameworks for advancing rights and teaching for } \\
\text { empowerment } \\
\text { July 2019: Paris International Conference, Innovating for girls' } \\
\text { and women's empowerment through education in partnership } \\
\text { with the G7 }\end{array}$ \\
\hline World Bank & $\begin{array}{l}\text { 2013-2017: Funded by the Global Partnership for Education, the } \\
\text { Pacific Early Age Readiness and Learning Program (PEARL) } \\
\text { improves school readiness and early literacy in Pacific island } \\
\text { nations }{ }^{i} \\
\text { 2014-2018: READ: Results for Education Achievement and } \\
\text { Development Project in The Gambia to improve access to basic } \\
\text { education, improve quality of teaching and strengthen education } \\
\text { systems }\end{array}$ \\
\hline
\end{tabular}

aUNICEF, “Nutrition.” https://www.unicef.org/eu/nutrition. Accessed February 25, 2020

bILO, "International Programme on the Elimination of Child Labour and Forced Labour (IPEC+)." https://www.ilo.org/global/about-the-ilo/how-the-ilo-works/flagships/ipec-plus/lang\%2D\%2Den/ index.htm. Accessed February 25, 2020; ILO, "International Programme on the Elimination of Child Labour and Forced Labour (IPEC+)." https://www.ilo.org/global/about-the-ilo/how-the-ilo-works/ flagships/WCMS_495567/lang\%2D\%2Dru/index.htm. Accessed February 25, 2020

"ILO, "Accelerating action for the elimination of child labour in supply chains in Africa (ACCEL Africa)." https://www.ilo.org/ipec/projects/global/WCMS_698536/lang\%2D\%2Den/index.htm. Accessed February 25, 2020

dILO, "Eliminating child labour and forced labour in the cotton, textile and garment value chains: an integrated approach." https://www.ilo.org/ipec/projects/global/WCMS_649126/lang\%2D\%2Den/ index.htm. Accessed February 25, 2020

"WHO, "Ending preventable child deaths from pneumonia and diarrhoea by 2025." https://www.who. int/maternal_child_adolescent/documents/global_action_plan_pneumonia_diarrhoea/en/. Accessed February 25, 2020

'WHO, “Global Strategy for Women's, Children's and Adolescent's Health 2016-2030.” https://www. who.int/life-course/partners/global-strategy/en/. Accessed February 25, 2020

gUNESCO, "From access to empowerment: UNESCO strategy for gender equality in and through education 2019-2025." https://unesdoc.unesco.org/ark:/48223/pf0000369000. Accessed February 25,2020

hUNESCO, "G7 France/UNESCO International Conference-Innovating for girls' and women's empowerment through education." https://en.unesco.org/events/g7-franceunesco-internationalconference-innovating-girls-and-womens-empowerment-through. Accessed February 25, 2020

"World Bank, "Early Childhood Development." https://www.worldbank.org/en/topic/earlychildhooddevelopment\#3. Accessed February 25, 2020

jWorld Bank, "GAMBIA-READ: Results for Education Achievement and Development Project." https://projects.worldbank.org/en/projects-operations/project-detail/Pl33079?lang=en. Accessed February 25, 2020 


\section{Global Social Policy on Children's Rights Between IMPLEMENTATION AND CONTESTATION}

As contemporary reflections on the meaning and implications of children's rights (particularly those promoted by the CRC) in 2020 have exposed, the adoption of a legally binding human rights treaty for children has had a catalytic effect on legal, political and societal change in most countries of the world. It has also led to a reconfiguration of global social governance, both in terms of the broader norms shaping global social governance and in terms of the transformations of international institutions and actor landscapes and constellations. Based on the CRC, more and more organizations active in development cooperation have been formulating, adopting and implementing child rights-based approaches to development; the number of independent national human rights institutions for children has significantly increased (UNICEF 2013) all over the world, and many countries have adopted National Plans of Action or changed national constitutions and law in order to reflect the obligations of their governments under the CRC. Long-standing think tanks and NGOs have created new departments or programming sections exclusively for children and youth, specialized research institutes dedicated to child-related issues have been established, and of course countless new civil society actors have entered the landscape of global social governance on children's rights. UNICEF, the largest intergovernmental organization (IGO) addressing the special situation of children, has reformulated its programming priorities by implementing a rights-based approach (RBA) with the Convention at its core. In this respect, the $\mathrm{CRC}$ can be seen as the principal driving force behind a global culture of children's rights and an ever-increasing salience of children's rights in international and domestic politics.

At the same time that efforts to implement children's rights domestically and internationally have accelerated, however, scholars have also started to question this (pre)dominance of matters of implementation in research on children rights, particularly a rather rigid and simple understanding of how international human rights standards are realized in domestic contexts (Holzscheiter et al. 2019). The contemporary debate on children's rights among scholars and practitioners, which has largely been informed by Postcolonial and Critical Theory, also brings to light moments and processes of contestation and resistance to a powerful global discourse on appropriate childhood encapsulated in children's rights standards, questioning the easy traveling of seemingly universal values across 
time and space. Authors who have assessed the relevance of the CRC in the Global South have pointed to a tension between these global ideals, on the one hand, and social and cultural practices in the Global South, on the other, looking, for example, at corporal punishment, child participation or working children (Balagopalan 2019; Fay 2019; Imoh 2019). Accordingly, contemporary engagement with children's rights in the context of global governance reconceptualizes the relationship between these norms and global and domestic institutions, policies and practices as more ambivalent and contentious, assuming that the meaning of such norms cannot be inferred and understood independently of the context (local, cultural, linguistic, political, historical, institutional etc.) in which they are debated and enacted (Wiener 2018; Kaime 2010). Following this twist in the debate on children's rights, scholarly interest has shifted toward regional human rights treaties and institutions (such as the African Charter on the Rights and Welfare of the Child, the ASEAN Commission on the Rights of Women and Children, the European Court of Human Rights, or Independent National Human Rights Institutions) as vital ingredients of a stronger cultural embedding of core principles and ideas codified in the CRC.

\section{Taming the Beast of Children's Rights-The Separation of Children and Youth Advocacy in Global Social Policy}

An analysis of the organizational landscape in which global social governance related to children's rights is taking place not only brings to light the strong diffusion of children's rights across most, if not all, international organizations (i.e. child rights mainstreaming) - it also exhibits conflict lines around the separation of children from other social groups enjoying special protective status in international politics, above all women and youth. More than ever, contemporary global social governance seeks to address adolescents and youth as a previously 'forgotten' group. At the same time, it can be argued that the separation of children's issues and youth issues which is visible when looking at the programming areas of international organizations is an artificial construct, particularly in light of the broad definition of 'childhood' under the CRC which includes children between 0 and 18 years of age. This arguably artificial separation can also be characterized as a more protective child rights agenda and a more emancipatory, agency-oriented youth agenda. It is reflected in the fact that most organizations maintain different programming sections on 
child-related issues (often associated with child protection) and on youth matters (often framed as matters of youth 'agency' or 'empowerment'). The Joint United Nations Programme on human immunodeficiency virus/Acquired Immune Deficiency Syndrome (HIV/AIDS) (UNAIDS) has separate program areas for 'children' and 'young people'. While the former targets unborn or very young children (i.e. pediatric HIV, seeking to eliminate new HIV infections in children), the 'Youth Programme' established in 2012 describes young people as beneficiaries, partners and leaders, seeking to "strengthen young people's leadership skills." ${ }^{10}$ Child (rights) focused global social governance thus testifies to dynamics of institutional fragmentation in which contentious issues in child-related social policies are relegated to the 'youth' realm in order to ensure governability (e.g. sexual and reproductive rights, youth unemployment, youth participation).

\section{IOs and Discourses on Childhood in Global Social Governance}

For many, the contemporary notion of children's rights encapsulates a rather specific ideal of childhood as a phase in life that is "free of responsibilities, which would include work, and dominated by education and leisure within the family context" (Baker and Hinton 2001, 190). In fact, children's rights as formulated in the CRC and interpreted by the CRC Committee continue to be challenged on the grounds of their modern, Western bias (Imoh and Ame 2012). Boyden, even if very tentatively, has insinuated that the CRC might be even more 'Western' in its character than other human rights treaties (Boyden 1997, 197). This Western bias expresses itself, after all, in an image of children as non-economic and non-political human beings. Although social policy issues still continue to be closer to a traditional discourse and focus on child rights as passive rights to protection, cross-cultural dialogue in the area of social policy and protection also appears to be more promising, as evidenced, for example,

\footnotetext{
${ }^{9}$ See for example UNDP's activities on "empowering youth" under the rubric of "Democratic governance and peacebuilding." https://www.undp.org/content/undp/en/ home/democratic-governance-and-peacebuilding/empowering-youth.html. Accessed February 25, 2020.

${ }^{10}$ UNAIDS, "Young people." https://www.unaids.org/en/topic/young-people. Accessed February 25, 2020.
} 
by the establishment of regional human rights institutions on child rights such as the ASEAN Commission on the Rights of Women and Children in 2010 or the creation of a Rapporteur on Children's Rights in the Context of the Inter-American Commission on Human Rights in 1998.

Notions of childhood primarily experienced in the global North, therefore, constitute a powerful leitmotif in global social governance as much as they are the target of contestation by different 'norm-antipreneurs' (Bloomfield and Scott 2018), many of whom are from the Global South. In fact, it is against the 'benchmark' of a globalized ideal of childhood and its core settings - home, school, family — that certain 'blind spots' in global social governance have become apparen, such as children living in the streets, or child-headed households. At the same time, it is above all in global social governance that dissident voices have made themselves heard and where demands for the recognition of children's economic agency, in particular, have also brought with them forceful claims for seeing children as social and political agents. With its long historical legacy, the international debate on appropriate rules and policies to regulate child work and abolish child labor is a showcase for contending philosophies on childhood and children's rights and the ongoing resistance to the social, economic and political agency of under-18s. On a more general level, these debates testify to the disputed nature of children's (transnational) citizenship, both in terms of the abstract sense (i.e. children as citizens with social and political rights) and in terms of concrete debates over nationality, citizenship and (un)equal access to social services (education, health, housing, social benefits).

\section{CONCLUSION}

As this chapter has demonstrated, international organizations are indispensable promoters of children's rights in global social governance. They pursue a wide range of activities geared toward the diffusion, implementation and concretization of international children's rights standards in global, regional and domestic social policy. Seeking to foster a growing and sustained sensitivity and commitment to children's rights in diverse social policy fields (education, health, food, housing), the financial contributions of international organizations have been particularly critical in low- and middle-income countries. While highlighting the manifold positive contributions of international organizations in making children's rights a systematic consideration in global social policy, this chapter has 
also sought to point to the contested meaning of 'children's rights' when it comes to accepting an image of children as direct and active rightsholders, including their right to participate in decisions affecting them. Incorporating children's rights in global social policy thus requires international organizations to consider these rights as consequential not only to the policies and programs they promote $v i s-\grave{a}$-vis individual countries, but also to their own polity and procedural rules, including the necessity to increase the participatory space and possibilities for articulation for rights-holders aged 18 and below.

\section{REFERENCES}

Baker, Rachel, and Rachel Hinton. 2001. "Approaches to Children's Work and Rights in Nepal." The ANNALS of the American Academy of Political and Social Science, 575 (1): 176-193.

Balagopalan, Sarada. 2019. "Why historicize Rights-Subjectivities? Children's Rights, Compulsory Schooling, and the Deregulation of Child Labor in India." Childhood 26 (3): 304-320.

Bloomfield, Alan, and Shirley V. Scott. Eds. 2018. Norm Antipreneurs and the Politics of Resistance to Global Normative Change. London: Routledge.

Boyden, Jo. 1997. "Childhood and the Policy Makers: A Comparative Perspective on the Globalization of Childhood." In Constructing and Reconstructing Childhood, edited by Allison James and Alan Prout, 190-229. London: Falmer Press.

Committee on the Rights of the Child. 2003. General Comment No. 5 on the General Measures of implementation of the Convention on the Rights of the Child. CRC/GC/2003/5.

European Commission. 2011. An EU Agenda for the Rights of the Child. Brussels: European Commission.

Fay, Franziska. 2019. "Decolonizing the Child Protection Apparatus: Revisiting Child Rights Governance in Zanzibar." Childhood 26 (3): 321-336.

Freeman, Michael. 1983. The Rights and Wrongs of Children. London: Frances Pinter.

Grugel, Jean. 2013. “Children's Rights and Children's Welfare after the Convention on the Rights of the Child." Progress in Development Studies 13 (1): 19-30.

Hammarberg, Thomas. 1990. "The UN Convention on the Rights of the Child And How To Make It Work." Human Rights Quarterly 12 (1): 97-105.

Holzscheiter, Anna. 2010. Children's Rights in International Politics: The Transformative Power of Discourse. Basingstoke: Palgrave Macmillan. 
Holzscheiter, Anna. 2018. "Affectedness, Empowerment and Norm ContestationChildren and young People as Social Agents in International Politics." Third World Thematics: A TWQ Journal 3 (5-6): 1-19.

Holzscheiter, Anna, Jonathan Josefsson, and Bengt Sandin. 2019. "Child Rights Governance: An Introduction." Childhood 26 (3): 271-288.

Imoh, Afua Twum-Danso. 2019. "Terminating Childhood: Dissonance and Synergy between Global Children's Rights Norms and Local Discourses About the Transition from Childhood to Adulthood in Ghana." Human Rights Quarterly 41 (1): 160-182.

Imoh, Afua Twum-Danso, and Robert Ame. 2012. Childhoods at the Intersection of the Local and the Global. Basingstoke: Palgrave Macmillan.

Kaime, Thoko. 2010. "Vernacularising'the Convention on the Rights of the Child: Rights and Culture as Analytic Tools." The International Journal of Children's Rights 18 (4): 637-653.

Khadka, Suman. 2013. "Social Rights and the United Nations-Child Rights Convention (UN-CRC): Is the CRC a Help or Hindrance for Developing Universal and Egalitarian Social Policies for Children's Wellbeing in the 'Developing World'?" The International Journal of Children's Rights 21 (4): 616-628.

Kišūnaite, Aida. 2019. "Children's Rights Protection in the EU: The Need for a Contextual Perspective." Peace Human Rights Governance 3 (2): 171-192.

Marshall, Dominique. 1999. "The Construction of Children as an Object of International Relations: The Declaration of Children's Rights and the Child Welfare Committee of League of Nations, 1900-1924." International Journal of Children's Rights 7 (2): 103-147.

McGillivray, Anne, ed. 1997. Governing Childhood. Aldershot: Dartmouth.

Nolan, Aoife. 2013. "Economic and Social Rights, Budgets and the Convention on the Rights of the Child." The International Journal of Children's Rights 21 (2): 248-277.

Rizzini, Irene. 2001. "On Cultural Diversity and Childhood Adversity." Childhood $8(3): 315-321$.

Rodham, Hillary. 1973. "Children under the Law." Harvard Educational Review 43 (4): 487-514.

Rosenblatt, Jeremy. 2000. International Conventions Affecting Children. The Hague/Boston/London: Kluwer Law International.

UNICEF. 2013. Championing Children's Rights: A Global Study of Independent Human Rights Institutions for Children. Florence: Innocenti Publications.

van Bueren, Geraldine, ed. 1993. International Documents on Children. Den Haag: Martinus Nijhoff.

van Bueren, Geraldine. 1998. The International Law on the Rights of the Child. Den Haag: Martinus Nijhoff. 
Vaughan, Rosie Peppin. 2010. Girls' and women's education within Unesco and the World Bank, 1945-2000, Compare: A Journal of Comparative and International Education, 40 (4): 405-423, doi: https://doi.org/10.1080/0305792 5.2010 .490360

Wiener, Antje. 2018. Contestation and constitution of norms in global international relations: Cambridge: Cambridge University Press.

Yeates, Nicola. 2014. Understanding Global Social Policy. Bristol: Policy Press.

Yeates, Nicola, and Chris Holden. Eds. 2009. The Global Social Policy Reader. Bristol: Policy Press.

Open Access This chapter is licensed under the terms of the Creative Commons Attribution 4.0 International License (http://creativecommons.org/licenses/ by $/ 4.0 /$ ), which permits use, sharing, adaptation, distribution and reproduction in any medium or format, as long as you give appropriate credit to the original author(s) and the source, provide a link to the Creative Commons licence and indicate if changes were made.

The images or other third party material in this chapter are included in the chapter's Creative Commons licence, unless indicated otherwise in a credit line to the material. If material is not included in the chapter's Creative Commons licence and your intended use is not permitted by statutory regulation or exceeds the permitted use, you will need to obtain permission directly from the copyright holder.

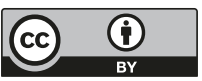

